\section{The storm of progress}

\section{Leonie Scholtz MB ChB, MMedRad (D)}

Department of Radiology University of Pretoria

The Swiss artist, Paul Klee, painted an obscure, but beautiful picture titled 'Angelus Novus'. In the painting he depicts the angel of history as though the angel is about to move away from something he is contemplating intently. His eyes are staring, his mouth is open, and his wings are spread. The eminent German philosopher and art critic Walter Benjamin referred to this painting in one of his theses on the philosophy of history: 'Like the angel, with our faces fixed to the past, we are propelled forward to the future by the force of history. We are driven by a storm which is called progress.'

I intend to paint a picture of how I see the future of radiology, not only at this Academic Hospital, but also as a science and profession in this country. And with reference to Benjamin I want to title my painting 'The Storm of Progress'.

\section{The history}

As an introduction I will dwell briefly on the history of this relatively young discipline in medical science. Radiology is very much part of the event of modernisation which announced itself just before the beginning of the previous century. The famous Eiffel tower was erected for the 1889 World Fair in Paris. The theme was Manufacturing and Transformation. This construction still symbolises the romance of technology and progress. I do not intend to recall the chain of events released by modernisation as if counting the beads of a rosary, but rather want to link the past with the present and the future by focusing on a few individuals without whose contributions modern radiology would not have been possible. The scientific achievements of these pioneers opened up new possibilities in medicine.

Wilhelm Conrad Röntgen discovered the X-ray on 8 November 1895 in Maximilian University in Würtzburg.

This achievement of Röntgen gave medicine a diagnostic tool. The medical practitioner, specifically the radiologist, was now able to diagnose the abnormal. It signalled the genesis of the art of looking, the art of visual discernment and diagnosis by means of electromagnetic waves of short wavelength. This was nothing less than a revolution in medicine.

Marie Curie and her husband Pierre were fascinated by the French physicist Henri-Antoine Becquerel's discovery in 1896 of the natural radiation of uranium salt. Their extensive research led to the discovery of radium and radioactivity. At the time the discovery rocked the world of science because it seemed to contradict the principle of the conservation of enernature of matter and inaugurated the his Institute for Physics at the Julius gy. It forced scientists to reconsider the era of particle physics.

Marie Curie's systematic research introduced radioactive materials in medical diagnostics and therapy. Her daughter Irene and son-in-law Frederic Joliot continued her work and discovered artificial radioactivity, which formed the basis of Nuclear Medicine. Marie Curie was the first woman to be buried in the Pantheon and possibly the greatest female scientist of all time.

The development of contrast media and its implementation in angiography soon followed Röntgen's discovery. Egas Moniz, a man of many talents (doctor, politician, senator), was the first scientist who conceived visualisation of cerebral blood vessels using contrast injection. In 1927 at an international meeting of neurologists he presented an account of a successful cerebral angiogram. With cerebral angiography one could now visualise intracranial tumours, vascular abnormalities and aneurisms.

In 1929 Werner Forssmann became the first to develop a technique for the catheterisation of the heart. This he did by inserting a cannula into his own antecubital vein, through which he passed a catheter for $65 \mathrm{~cm}$. He then walked to the Xray department where a photograph was taken of the catheter lying in his right auricle. Despite the significance of his discovery, Forssmann was scorned by his peers. His self-experimentation led to his dismissal. It was only many years later that his pioneering efforts found recognition.

The development of the Seldingerneedle by Sven-Ivar Seldinger in 1953 was the genesis of modern angiography. With the Seldinger Technique a percutaneous insertion is made preferably in the femoral artery. A 
guide wire is inserted through a thin walled needle and then a plastic preformed catheter. Access can be gained to any part of the body via the cardiovascular system. Today this technique is applied in virtually every angiogram.

Charles T Dotter introduced a paradigm shift in radiology on 10 June 1963 at the Czech Radiological Congress. His presentation 'Vascular catheterization and angiographic techniques of the future' gave a complete overview of catheter angiography, and subsequently discussed new and future techniques including his most adventurous technique, catheter endarterectomy. He finished with an historic conclusion, which laid a foundation for interventional radiology: 'The angiographic catheter can be more than a tool for passive means for diagnostic observation; used with imagination it can become an important surgical instrument.' A few months later, on 16 January 1964, Dotter performed the first percutaneous transluminal angioplasty of a stenotic femoral artery.

The first neuro-interventional case in South Africa was performed by our own Prof. Marthinus Janse van Rensburg of the Department of Neurosurgery together with Dr Bloch from Johannesburg on 19 March 1976, when they injected silicone particles into a large posterior fossa AVM.

It can be said that the X-ray has proven to be the greatest technological medical miracle of the 20th century. But it was not until the development of the computer and the genius of Godfrey Hounsfield who realised that $\mathrm{X}$-ray images could be stored and manipulated by computers, that Xrays were used in an amazingly accurate diagnostic device known as com- puterised axial tomography, or the CAT scanner. The announcement by Hounsfield, at the 1972 British Institute of Radiology Annual Conference, of this machine was the greatest technological step forward in radiology since Röntgen's discovery.

Another milestone was the discovery of the magnetic resonance phenomenon by Felix Bloch and Edward Purcell in 1946. In the period between 1950 and 1970 nuclear magnetic resonance (NMR) was developed and used for chemical and physical molecular analysis. In 1971 Raymond Damadian created one of the most useful diagnostic techniques of our time, magnetic resonance imaging (MRI) scans. This procedure allows radiologists to non-invasively image the human body in meticulous detail.

\section{Die hede}

Ek het die verlede met enkele breë kwasstrepe geskilder en ek glo dat hierdie beeld van die ontwikkeling wat ons soos 'n storm voortgedryf het vanaf die begin van die vorige eeu tot en met die 21e eeu, dit duidelik maak dat die rol en implementering van die sogenaamde Röntgenstrale asook ander beeldingsmodaliteite enorme dimensies aangeneem het. Waar staan ons vandag en watter rol speel die radioloog in Suid-Afrika, beide in die diagnostiese en terapeutiese arena?

Wat die diagnostiese ontwikkeling betref kan ons die volgende konstateer:

1. Konvensionele X-strale het ontwikkel om maklik beskikbaar te wees vir almal. Maar met nuwe en kragtiger rekenaars en digitalisering ontwikkel ons vinnig na sogenaamde filmlose departemente waar opnames nie net onmiddellik beskikbaar is vir die radioloog op sy skerm voor hom nie, maar waar dit letterlik binne sekondes via telefoon of satelliet dwarsoor die wêreld versend kan word.

2. Rekenaartomografie beweeg na al hoe vinniger opnames met sogenaamde 'multislice' tegnologie, met beter resolusie en laer stralingsdosisse. Drie-dimensionele rekonstruksies vergemaklik diagnose en chirurgiese beplanning. Vate en hol organe kan endoluminaal herkonstrueer word.

3. MR-beelding het sekerlik die grootste impak gemaak op diagnose sedert die ontdekking van $\mathrm{X}$-strale. Dit kan op elke moontlike dissipline toegepas word. Weereens neem die spoed van prosedures toe en die resolusie verbeter. Waar MR aanvanklik primêr gefokus het op beelding van neurologiese en muskuloskeletale toestande is daar die afgelope paar jaar enorme ontwikkeling ook op die veld van die kardiovaskulêre stelsel. Die longvelde sowel as die buik en bekken word ook nou verbeeld. In baie Eerste wêreldlande het sg. magnetiese resonansie cholangio-pankreatografie (MRCP) die meer indringende endoluminale retrograde cholangiopankreatografie (ERCP) ondersoek vervang.

4. Wat ultraklank betref het die resolusie geweldig verbeter met die koms van sg. 'powerdoppler' en 'tissue harmonics'.

5. Die ontwikkeling van die foton emissie tomografie (PET) skandeerders het kerngeneeskunde se rol in diagnostiese radiologie gevestig.

Röntgen se ontdekking het dus uitgebrei na elke dissipline in die medisyne waar diagnose ter sprake is.

Ek het ook in die historiese oorsig van die ontwikkeling in radiologie spesifiek melding gemaak van die paradigma verskuiwing wat plaasgevind 
het. Die rol van die radioloog het die afgelope 40 jaar uitgebrei deur die radioloog se toetrede tot die terapeutiese behandeling van die pasiënt.

1. Wat die kardiovaskulêre stelsel betref, vorm die intervensionele radioloog deel van 'n span met die implementering van ballonangioplastie prosedures, stent of stentgraft inplantasie asook arterektomie en trombolise. Aneurismes of disseksie van die aorta kan sedert 1994 endoluminaal hanteer word en sodoende kan die mortaliteit en morbiditeit van ingrepe dramaties verlaag. Deur 'n klein insisie in die lies kan ons perkutaan 'n sg. stent graft prostese inplaas en 'n aneurisme herstel waarna die pasiënt binne 'n uur 'n koppie tee kan geniet en die volgende dag huis toe gaan. Torakale aneurismes, disseksie of ruptuur kan ook so hanteer word. Uitstekende opvolg rekenaartomografie (RK) beelde kan na so 'n prosedure die resultaat evalueer.

2. In die gastro-intestinale stelsel is ons betrokke by die inplasing van biliêre stents en sogenaamde transjugulere portosistemiese omleidings (TIPS) prosedures, asook embolisasie van gastro-intestinale bloeipunte.

3. Die intervensionele neuroradioloog kan nou intrakraniale aneurismes emboliseer of arteriële malformasies emboliseer.

4. So is daar ook 'n rol in uroradiologie met die inplasing van nefrostomie dreinasiebuise en die perkutane verwydering van stene.

5. 'n Relatief nuwe rol is die embolisasie van uteriene miome wat wêreldwyd sterk gevestig word.

6. Die intervensionele radioloog kan boonop biopsies neem van letterlik enige tumor. Chirurgie kan vergemaklik word deur voorafgaande embolisasies. Selfs terapeutiese embolisasies kan chemoterapie komplementeer.

7. Tans kan ons enige vernouing in enige arterie of vena dilateer en ook, tydens beskerming distaal, vernouings in die karotisvate dilateer. Sodoende voorkom ons distale embolieë en die gevolglike katastrofe van 'n beroerte.

8. Die nuutste ontwikkeling van die sogenaamde 'drug eluting stents' is sondermeer die mees dramatiese ontwikkeling wat die eliminasie van herstenose betref. Die Wall Street Journal het in 'n voorbladartikel hierdie ontwikkeling as die geboorte van 'n biljoen dollar industrie aangekondig.

9. Nog 'n interessante ontwikkeling is die sg. magneetgedrewe kateterisasie en stereotakse waar beide X-strale en MR aangewend word vir kateterisasieprosedures sowel as vir kardiale ablasie.

10. Nie alle intervensionele prosedures was egter suksesvol nie. Laser tegnologie het ' $n$ opwindende veld geopen om plaak en herstenose te behandel, maar dit was 'n mislukking en menige laser apparaat staan tans ongebruik in die kelderverdiepings van baie hospitale.

\section{Progress surpassing the art of looking}

Have we reached a point where progress has actually surpassed the art of looking or the art of visual discernment? Let me explain my question.

A colleague and friend recently made the remark in a discussion that nowadays we see too much. In other words, advanced radiological technology has eliminated the art and skills required in the past. The art of looking, of thinking with our eyes, has become redundant. For example, before our magnificent $\mathrm{CT}$ and MR images, we used simple measurements on angiograms to establish the presence of an intracranial tumour. Distortion of the so-called Sylvian triangle could give an indication of a possible intracranial lesion skillfully observed by a radiologist or neurosurgeon. Today we simply do a 2-minute MRI to locate the tumour. We can even get close to a histological diagnosis if we inject contrast or do spectroscopy. Has progress alienated us from the art of healing? The Germanic languages have traditionally spoken of medicine as both 'geneeskunde' and 'geneeskuns'. Has the latter, 'geneeskuns', become a victim of progress?

I would certainly answer in the negative under the following conditions:

- Not if the radiologist applies his/her extensive knowledge of physics to offer the clinician the best imaging modality of choice to identify a certain condition.

- Not if the radiologist applies this knowledge to obtain the best diagnostic images with the least risk or harm to the patient.

- And certainly not if the radiologist continues to apply all the conventional rules of radiology: to recognise what is normal and abnormal; to have a profound knowledge of anatomy; and to use his/her expertly trained eyes on what still remains variations of black and white.

The art of healing has always included the craftsmanship of the practitioner as well as the application of the scientific advancements in medicine, the progress made in both 
knowledge and in technology. The storm of progress has taken medicine by force, but it is a challenge that we may not evade or neglect at any cost.

In his inaugural address the Principal of the University of Pretoria underscored that in order to survive and develop as an academic institution, it is essential to be internationally competitive. He forwarded convincing statistics and figures to back his arguments and he highlighted the present shortcomings in our international ranking. Should the criteria be applied to the Radiology Department of this University, the following must be said.

We need state-of-the-art equipment and we need expertise to work in the department and train the students. The equipment of the Department is insufficient and outdated. The average age of the equipment exceeds 15 years. We still do not own an MR, which nowadays plays a major role in diagnostic radiology and training of registrars. We are not equipped with a mammography unit for diagnosis or for screening. Our Nuclear Department is the worst off, with extremely outdated equipment.

It is unfortunate, but true, that at this stage we cannot compete with any of the private practices in Gauteng, not to mention our position in the international arena. Fortunately the present circumstances should change with the opening of the new Pretoria Academic Hospital. It is expected that the Department will be equipped with the latest developments in X-ray facilities.

What about the expertise in our Department?

Like many other departments, the Department is currently understaffed, with a massive workload and not enough consultants. This obviously reflects on the quality of reporting and leaves little time for research possibilities and publications.

It is essential that we consider the function of this University, and specifically the Medical Faculty, in the socio-political context of this country. In terms of the Bill of Rights every South African should have access to good health care. Good health care not only entails adequate sanitation, immunisation and TB screening, it also entails good tertiary referral facilities. The patient diagnosed with TB in the primary facility is surely not only entitled to TB medication. When the patient develops a life-threatening episode of haemoptysis, should the patient not be entitled to embolisation of his bronchial arteries by a welltrained interventional radiologist? I believe the patient living in the rural area who develops claudication should, instead of undergoing an amputation, have access to a tertiary medical facility where a well-trained expert can do an interventional procedure. The increasing AIDS epidemic has also become a threat to the vascular system where we now see advanced aneurismal and occlusive disease in very young patients. Surely we cannot simply ignore the pathology. The interventional radiologist has an obligation to salvage their limbs and treat their aneurysms. In radiological terms this treatment includes performing endoluminal procedures, the early diagnosis and treatment of cancers or infections, the embolisation of life-threatening haemorrhage, and the treatment of aneurysms with stent grafts. The new development of teleradiological services could give patients in rural areas easy access to diagnostic consultation. This service should be expanded to each and every clinic in the rural areas and linked up with an institute such as ours.

\section{Academia, private sector and government}

One of the major challenges facing us in the establishment of a centre of excellence is the question of financing the costs.

I have entered into the academic field after 16 years' experience in the private sector. I intend to form an alliance with my colleagues in the private sector by which they will become part of this Department to share their knowledge and experience with the prospective radiologists. I also see the formation of partnerships with the major enterprises in the medical field as one of our biggest challenges and goals to achieve.

The government has budget restraints. Although the budget for health increases every year, the percentage of the GDP is on the decline. Furthermore, medical inflation is believed to be higher than in other sectors of society. We can no longer live with the expectation that government will finance our future developments. What we can do however is to think innovatively, coming up with ideas how government can make it attractive for the private sector to invest in the tertiary health care sector, specifically in the financing of hi-tech apparatus, without which we cannot hope to achieve our mission goals. Lowering the tax burden for private donors or investors could be an option.

The downside of the technological advancement is the excessive costs, the upside, however, is that the centres of 
excellence could attract private patients and therefore to a large extent begin to pay for themselves. The Radiology Department would be able to offer private patients interventional procedures as well as sophisticated MR imaging. The generated revenue can be utilised for the upgrading of equipment, research, educational material and bonus payments. This may also attract experts to return to the academic environment or to consider partnerships. Whist on this subject, allow me to look briefly at the cost implications of interventional procedures. Reduction in the overall treatment cost for the Government Health Service by means of intervention is not always appreciated. Although the average endoluminal devices are rather costly, the cost of hospital stay including ICU, especially for a thoracotomy or abdominal aortic aneurysm (AAA) repair, surpasses that of an endoluminal procedure. Interventional procedures can ultimately reduce cost. In addition to the cost saving factor, the mortality and morbidity is also substantially lower. To give an example: the mortality rate for an open surgical repair for a ruptured thoracic aorta approaches 35\% whilst for endoluminal repair it is less than $16 \%$.

With regard to medical training and the lack of funds, we cannot venture into the future without partnerships with the private sector. Most medical faculties lack the equipment needed for postgraduate training. Government has however committed itself to Private Public Partnerships. Should we negotiate an agreement with the private sector on training, I want to propose the following:

1 . In the event of expertise or technology not being available at an acad- emic institution, the secondment of a registrar to the private sector for short periods, in the rule not longer than 3 months, must be considered.

2. The Academic Department can give accreditation to the private institution or practice for the training to be recognised. This will also entail that the private sector doctors receive a fellowship, or honorary lectureship, that they become part of the Departmental Academic team, and that they form part of the examination board of the Department.

\section{Medicine in a postmodern world}

The contemporary German philosopher, Peter Sloterdijk, in a paper on medicine's search for excellence, made the observation that all cultures have in common the drive for immunity. Man thus longs for an existence free of physical taxation and spiritual taxation, free of abnormalities and foreign agents that threaten his equilibrium. Immunity is understood as the experience of well-being ('in Ordnung Sein') of living systems. $\mathrm{He}$ argues that historically speaking pre-modern man distinguishes himself from modern man only in this respect, that the pre-modern man relies or insures himself with experiences (in many cases superstitions) that offer vague immunity, whilst modern man in a progressive fashion has come to rely on techniques that offer him exact immunity. The paradigm of the latter can be found in the emergence of the insurance industry, the technological development since the 18th century, and specifically in the development of modern medical science. It is not by chance that the socalled health industries find them- selves in the forefront of Fortune's top 100 companies. He makes the proposition that we must not forget that medicine is one of the few remaining utopian enclaves in a demystified (read: post-modern) world. Every healing that is enacted bears in it the original promise of a modern world, that we are progressively moving to a better world - socio-politically as well as bio-politically. The mentioned triad (insurance, technology and medicine) has established a new type of social contract, a contract that improves the chances between people, or, in his jargon, that optimises immunity.

I find Sloterdijk a very convincing cultural analyst, and I therefore propose that it is in the interests of the triad to invest in medical care and technology. I am also firmly convinced that the government as facilitator of social contracts can assist enormously in this respect.

\section{Toekomsperspek- tiewe}

Waarheen dryf die storm van vooruitgang ons heen? Wat is die toekoms van radiologie as beroep? Watter uitdagings staan ons te wagte in die toekoms?

Ons kry al hoe meer te make met'n interne konflik van belange.

In teenstelling met die chirurg, internis, pediater, uroloog of neuroloog, is die radioloog ' $n$ diensverskaffer. Die klinikus kan funksioneer sonder die radioloog, maar die radioloog kan nie funksioneer sonder die verwysing van die klinikus nie. Feit van die saak is dat die radioloog nie 'n monopolie of alleenreg op sy kundigheid het nie. Die oorname van beelding deur ander mediese dissi- 
plines met die gevolglike uitsluiting van die radioloog, het 'turf battles' in die lewe geroep.

Daar is twee moontlike metodes om hierdie sogenaamde 'turf battles' te oorkom. In die eerste plek moet superspesialisasie plaasvind wat elke radioloog in 'n posisie van uitnemendheid plaas. Die intervensionele radioloog sal in die toekoms toegerus moet word met die volgende vaardighede: beeld vaardigheid (imaging skills), kliniese kundigheid, intervensie vaardigheid, en kennis van genetiese ingeneurswese (genetic engineering).

In die tweede plek moet samewerkingsooreenkomste binne'n etiese raamwerk tussen die rolspelers daargestel word, dit is tussen die radioloog en die kardioloog, die vaskulêre chirug of die neurochirurg.

'n Verdere moontlikheid wat al hoe meer aan die orde van die dag is, is die totale omkering van die tradisionle rolverdelings. Die vinnige en maklike verkryging van heelliggaambeelding, met die voordeel dat dit binne sekondes verkrygbaar is, en totaal nieindringend is, open die moontlikheid dat die pasiënt direk van die algemene praktisyn na die radioloog verwys word wat op sy of haar beurt die pasiënt met ' $n$ diagnose verwys na ' $n$ klinikus in 'n ander dissipline vir verdere hantering.

Moderne tegnologiese ontwikkeling het radioloë met finansiële probleme belas wat buite hulle normale kundigheid lê. Radiologie as beroep het al hoe meer ontaard in 'n reuse industrie. Naas die finansiële bestuursvereistes, het die negatiewe wisselkoers van die Rand 'n groot las op privaatpraktyke sowel as op die publieke gesondheidsdienste geplaas.

Is daar enige oplossings?

Ek antisipeer dat in die toekoms die sogenaamde professionele praktykbestuurder 'n onmisbare lid sal wees van elke radiologiepraktyk.

Met betrekking tot die groeiende kapitaaluigawes antisipeer ek dat groot finansiële instansies die aankoop van apparaat sal probeer oorneem. Dit sal egter groot kontroversie uitlok.

Die ontwikkelende teleradiologiese dienste kan die sentralisasie van appa- raat uitvoerbaar en prakties maak.

Die moontlikheid van samesmeltings van praktyke - soos wat in ander professionele beroepe plaasgevind het - tot dié mate dat ons in die toekoms die verskynsel van internasionale praktyke mag sien, sluit ek glad nie uit as die oplossing vir hierdie probleem nie.

Medical science has not escaped the storm of progress, au contraire; the fact that we have a higher life expectancy today than at any other time in the past is due to the advances made in the field of medicine. But in spite of the breathtaking developments that have taken place, especially in the last century, some of which I had the opportunity to show to you tonight, I am reminded of what Marie Curie once said: 'One never notices what has been done, one only sees what remains to be done'. I concur with Sloterdijk, that the science of modern medicine is one of the few remaining utopian enclaves promising us a better world — bio-political as well as socio-political. Our quest for excellence is fuelled by that promise. 